\title{
PRIMARY SCHOOL TEACHERS' APPROACH TO ADVANTAGES OF ICT USE IN EDUCATION
}

\author{
Rasa Braslauskiene \\ Gražina Šmitienè \\ Reda Vismantienè \\ Klaipeda University, Lithuania
}

\begin{abstract}
The article reveals primary school teachers' approach towards advantages and disadvantages of information and communication technologies, their influence to children education as well as teacher experience in the application of ICT technologies in primary education and opportunities of teachers in the development of professional competence. Qualitative study (structured interview) was carried out which involved the teachers of $1-4$ forms more than four years actively using ICT in the classroom. According to the teachers, Content analysis of the study results revealed essential factors and potential ways of more efficient use of ICT in primary education, i. e .improvement of teachers' special professional competence (knowledge, skills and ability to use various ICT tools in the classroom, identification of special needs of primary school children, linking the development of formal and informal needs, etc.), personal viewpoint to ICT in social life, the shortage of ICT tools in primary school.
\end{abstract}

Keywords: primary school teachers, information and communication technologies (ICT), primary education, teachers' professional competence.

\section{Introduction}

Modern school is an integral part of changing society and most of the current problems of society are reflected in school life. Global and technological society copes with new challenges of economical effectiveness, social and cultural literacy through more productive information and communication devices and technologies. Fast change of information communication technologies and still growing supply becomes a challenge to the young generation. School communities choose a similar way dealing with educational problems arising at school. Information and communication technologies (ICT) are becoming increasingly important in educational system. Modern information tools and technologies are promoted to use at all levels of education process teaching and learning different things. These provisions are established in the EU's strategy documents, covering all areas and levels of teaching and learning. 
It is natural that substantially altering technological teaching facilities at comprehensive schools teachers of primary classes lack competence in purposefully using modern technologies and software in teaching process and planning their work using ICT as well as trying to know the pupils. These and other trends of ICT tools installation in schools are noticeable in national and international research and in the reviews of education state (Digital Agenda for Europe, 2010; Survey of Schools: ICT in Education, 2013; Ranguelov et al., 2011; Wastiau et al., 2013; Kampylis at al., 2015; Kalvaitis, 2014; Labute \& Žemaitaityte, 2015, et al.) Education reviews state that Lithuanian general education teachers are increasingly using ICT tools, more than a third of $4^{\text {th }}$ and $8^{\text {th }}$ form pupils is sufficiently provided with ICT tools, teachers frequently use them during lessons. According to the data of the international research, $58 \%$ of Lithuanian primary classes are only partially equipped with the means of ICT, and even $22 \%$ of $4^{\text {th }}$ form teachers systematically use ICT measures in class (about $24 \%$ of lessons) (Ranguelov et al., 2011). This indicator is lower than EU average. The review emphasizes that the teachers of primary and general education in Lithuania can expect timely help in various areas related to ICT software. Primary school teachers more frequently apply ICT measures for the subjects of natural and social sciences. International research of the state of education focus on the earlier and more diverse use of ICT measures in education as this helps to individualize teaching and learning, allows to apply various teaching methods and to form self-dependent learning skills, teaches digital and basic literacy, provides additional communication opportunities (Wastiau et al., 2013; Survey of Schools: ICT in Education, 2013; Ranguelov et al., 2011; Kampylis et al., 2015; Labute \& Žemaitaitytè, 2015, et al.). The launch of the renewed Programs of primary and basic education and taking into account the results of national and international research, the need for the primary school teachers to focus educational process on general and subject-specific competencies as well as to improve primary education quality in Lithuanian schools of general education arose. Systematic application of ICT measures and the pursuit of primary education quality are challenges dealt with by Lithuanian primary school teachers. According to Kalvaitis (2014), one fifth of primary school teachers has quite good preparation to use ICT because they use ICT tools in their classes systematically.

A new approach to primary education outcomes obligates to change the viewpoint not only to the content of education, the means of its realization but also to the pupil. The pupil is not framed in a certain work place - forms and methods of didactic activities have to be thought over so that learning can take place in different environments. According to Targamadzé et al. (2015), classroom doors should open because the children of $Z$ generation require a wider range of learning space as well as the need to harmonize both real and virtual 
learning spaces. The children of this generation do not like monotony - in virtual space they are accompanied by images, sounds, etc., the information is presented in an attractive form - all this should also be assessed in real space. The opportunity to participate in the development of learning environment is also important to the pupil (Targamadzè, 2014). A teacher should consult him and help to orientate in both real and virtual worlds as a child often does not feel their boundaries. The child should be encouraged to develop appropriate learning conditions in the real space and taught to use virtual space as the means to achieve certain purposes rather than treat it as a residence area. ICT enables to see the environment not only in the classroom, but also outside it; that is why innovation becomes even more attractive to the whole school community. According to Ranguelov et al. (2011), Gudoniene et al. (2013), Targamadze et al. (2015), Labutė and Žemaitaitytė (2015), mobile devices can be used for learning anywhere: in the classroom, in the corridor, in the school yard, in the park or a museum - this opens up new spaces and possibilities.

The aim of State education regulating documents is to define concepts suitable for modern educational environment (The Concept of a Good School (2015). Exclusive features of the environment are referred to dynamism and openness allowing pupils to flourish freely themselves: "Educational environment is open - traditional classroom spaces shift to classrooms without walls: educational process can take place in the corridors, in the lounges, in the library, in the school yard and in other internal and external school spaces. Classrooms are comfortable, functional, easy to adapt, pleasantly colourful, stimulating thinking, creativity and learning. Opportunities to learn both individually and in groups, in silence and communicating, cleanly and using different oiling materials and tools are provided (The Concept of a Good School, 2015). So what regards the use of ICT, it is essential to emphasize not only organization of learning process, but also to use these tools to create a variety of learning environments. In this case, primary school teachers' attitude towards ICT, their competence to use ICT tools in education, assessment of their advantages and disadvantages, consistent improvement of their competence in this field become important (Saylik \& Kalesnikiene, 2013). International research which compares the experience of EU countries in the development of application of ICT tools at school emphasizes that almost half of Lithuanian primary school teachers spend more than 6 days a year for the competence development seminars (EU average is $48 \%$ ) (Survey of Schools: ICT in Education, 2013). The recent research analyse the interface between information literacy and application of ICT in education. Kalesnikienès and Saylik (2013), Saylik (2010) research shows that information literacy, comprehension of information skills and abilities allow primary school teacher develop his skills to apply ICT in educational process focusing on thinking development of primary school children, which is especially important. In the 
research of this area, ICT tools are called educational entity, the third participant of education environment, supplementing the dyad of the teacher and the pupil (Prensky, 2001; Dagiene \& Kurilovas, 2008; Brazdeikis, 2009; Duobliene, 2010). However, it is not enough for a teacher to have ICT basics; it is important that both the teacher's own learning and professional development were based on a comprehensive application of ICT measures, that the teacher was interested in and searched for new measures of ICT, the ways to use them, was able to assess and to make out advantages and disadvantages of ICT measures, i.e. was digitally confident and supportive (Wastiau et al., 2013). In Lithuanian schools, digital and various educational means are more frequently used by the teachers having less than 15 years of teaching practice and working in city schools (Kalvaitis, 2014). In the previous works of Lithuanian researchers of the beginning of the XXIC, in the use of ICT and innovations in education the topics were analyzed in various aspects: ICT implementation in education was analyzed by Dagiene and Kurilovas (2008); the innovative operating assumptions for school head - by Budreckienè and Janiūnaitè (2010), creative application of innovations was analyzed by Gudoniene et al. (2014), Brazdeikis and Masaitis (2012) and Brazdeikis (2009); Gudynas et al. (2010) wrote about innovative teaching methods and their application to improve the quality of primary teaching and learning; the constant ongoing changes in science, technology and social space as well as teachers' competence were investigated by Juceviciene and Brazdeikis (2012); Targamadzė et al.(2015) investigated the contexts of virtual educational reality.

In science investigations perceiving the teachers' attitude towards educational innovations and the connection of their implementation success the unanswered question still remains: what advantages of the use of ICT in education see primary school teachers and how it determines their professional activities. The goal of the study: to determine primary school teachers' approach to advantages of the use of ICT in education.

\section{Research Methodology}

In order to investigate primary school teachers' approach to advantages of ICT tools in education, a qualitative study was chosen (half structured interview). At this point of the problem research it was decided to go deeper into the 1-4 form teachers' experience using a variety of ICT tools. According to Creswell (2009), a qualitative study helps to know the analyzed phenomenon better, to find out its characteristics, to reveal the peculiarities of viewpoints.

For the study to carry out a half structured interview with 20 teachers from 5 Klaipeda city schools was chosen, i.e. 5 teachers from each school working in different 1-4 forms. Later, the informants were requested to clarify certain aspects 
of the problem under investigation in writing. For the selection of the informants criteria selection was applied. All of the informants were women. The requirement for the teachers participating in the study was to have the experience of the use of various ICT tools in their work no less than 4 years. The teachers' average teaching experience had to be 17 years. It was important to investigate and to find out what teachers working with pupils of 1- 4 forms think about the advantages of ICT in educational process, what problems of their application in teaching they come across most often, what teaching and learning problems they solve using ICT, how they improve their professional competences in this field.

Carrying out content analysis of the interview results the aim was to emphasize the statements which highlighted essential, according to the informants advantages and reasons (e.g. the best, the most often, the easiest, the most important, essential, basic, first of all, etc.) and received the approval of most of the informants. A lot of answers coincided. The statements of the informants during the content analysis were divided into several categories and subcategories (Creswell, 2009). Discussing primary school teachers 'approach to ICT tools in education, it was necessary to find out what tools are used in primary education. Opinions of the informants were grouped, according to frequency of their use (most of them were mentioned by informants). Advantages of the use of ICT in primary education classes were divided into four subcategories: the use of ICT in classes of several subjects, promotion of pupils' learning, education of pupils with special needs, integration of educational content (table 1).

The Research Instrument. The questions formulated for the informants were divided into several blocks: ICT tools in primary education, advantages of ICT tools in primary education, development of a primary school teacher competence to use ICT tools.

\section{Research Results and Their Discussion}

All primary school teachers having participated in the study emphasized that they use a few ICT tools, i.e. they regularly use the tools they have in their workplaces. The teachers pointed out that in their personal life they can use and know more ICT and technical means, but that they lack this variety at work: " $a$ great tool is Kahoot, however, there is only one computer in the classroom and

not all the pupils have got mobile phones", "great website, but only for work at home", "classrooms lack computerized workplaces", "it is not always easy to coordinate employment of computerized classes", etc. The informants most frequently mentioned Interactive whiteboard and multimedia (MS PowerPoint presentations) and other technical tools: SMART board; multimedia-projector; computers (stationary, tablet PCs); mobile phones. 
According to the EU research in the state of education, in Lithuanian primary schools smartphones are scarcely used, one stationary computer is for six pupils. A similar ratio is for laptops and projectors. That is significantly worse ratio than EU average (Ranguelov et al., 2011; Survey of Schools: ICT in education, 2013). The data of the research confirm this tendency.

In their studies, Gudynas et al. (2010) and other researchers mentioned that various ICT tools are used to provide pupils with the widest possibilities to actively participate in educational process, in discussions and projects, i.e. stationary computer and laptop, multimedia projector, copier printer, mobile phone, video and audio players, TV set, film screening equipment, audio and video recording equipment, calculators, interactive whiteboard, microphone headset, computer video camera, graphic projector.

ICT tools most frequently used by the teachers who participated in the study enable them to effectively individualize pupils' learning, to encourage their conscious learning. It could be pointed out that some informants as one of the ICT advantages named intercourse with parents.

Though according to Dagiene and Kurilovas (2008), Brazdeikis (2009), Gudynas et al. (2010), properly applied new information technologies bring many new opportunities in communication with pupils' parents. The Internet, e-mail conferences, and school or teacher web pages become one of the most effective ways of teachers' and parents' communication and collaboration.

During the lessons, ICT tools (computers, tablets, multimedia-projectors) are used by most primary school teachers as video players, for the review of educational and feature films and their clips. All primary school teachers having participated in the study said that for educational process they look for and find information in media portals (lrt.lt/for children, youtube.com, etc.).

During the interview, primary school teachers named these frequently used ICT tools: internet and computer programs, online applications, media Portal, online games, virtual teaching aids/ textbooks. According to primary school teachers, all the groups of used tools programs or applications mentioned have great advantages: perfect Lithuanian, simple to use for children, easy to link to the content of primary education program, the possibility to work at home. Most frequently mentioned disadvantages are the lack of technical tools for each pupil and the possibility to work in bigger groups: "a great tool is smart robots however, not all can use them in the lesson", "pupils like tasks on the interactive board, but while one or two work others only watch and everybody knows that pupils like team work". The data of the research confirm the fact that primary education classes have got only partial provision of digital means (Survey of Schools: ICT in Education, 2013).

Primary school teachers, comparing various ICT tools, named the teaching aids which they use to prepare for classes. The most frequently used aids, 
mentioned by the informants are MS Power Point and MS Movie Maker. The tools for creating presentation are best known and especially liked by the teachers. They are most easily applied by them therefore, they are systematically used. According to the teachers: "in this way it takes me very little time to prepare for lessons", "I myself install video material for the lesson and I can show it to the whole class", "I already know what quality views the class needs", "Kahoot" is a great tool, but you need to have several computers in the classroom", "I myself have prepared a test (MS PowerPoint) for the whole class", etc.

Primary class teachers discussing the tools point out that namely the tools they know best, are used by other teachers of the school, but they do not know anything about other teaching aids or they have not been taught how to use them, eg.: prezi.com, projeqt.com, present.me, etc. Interactive whiteboards adapted to demonstrate interactive slide shows as well as their scenarios help to create an active lesson, where slides are used to interest pupils, to highlight the urgent topic, to present new material, to consolidate knowledge and abilities, to assess and evaluate themselves. Presentation scenarios are a methodological support for teachers preparing for the lesson and during the lesson. It should be noted that the teachers having participated in the study do not mention insertion virtual learning environment in primary education lessons or as the means of the development of their professional competence.

The importance of the use of the virtual environment educating pupils' digital literacy is indicated in scientific research and education state reports (Kampylis et al., 2015; Ranguelov et al., 2011; Wastiau et al., 2013; Labutė \& Žemaitaitytè, 2015, et al.).

Though part of the research stressed that digital speech and digital images for teachers (digital immigrants) are not natural communicative means (Prensky, 2010; Saylik, 2010; Targamadze et al, 2015), however, the participants of the research emphasized the benefits of ICT tools in creating visual information, easy communication with children (digital native), etc. In the guidelines of Information Technology change of 2014-2020 (2014) the purpose is pointed out that ICT were used no less than $20 \%$ of the formal education time and that elements of ICT were integrated into traditional subjects. The ICT tool variety mentioned by the informants allows to state that this purpose is fully put into practice. According to the informants, "having a better supply of ICT it would be possible to use it even more often".

Participants of the research discussing benefits of smart board usage emphasized semi finished tasks and games which can be found on the Internet websites. Some websites were distinguished as mostly used by many teachers (ismaniejirobotukai.lt; smalsutis.eu; pradinukai.lt; peliukai.lt; etc.). Only some teachers mentioned their preference to Internet appliqués. They make animated tasks and educational material themselves. It should be noted that teachers of 
primary school highly appreciate the opportunity to create or modify various internet tasks, not to use tasks prepared in a unified way.

Teachers learn about the possibilities to use Internet websites and teaching tasks from their colleagues or from training events. According to Bradeikis and Masaitis (2012), Gudynas et al. (2010), Budreckiene and Janiuniene (2010) and others, a better usage of ICT in the educational process ensures proper professional development of teachers. Gudynas et al. (2010) emphasizes the usage of ICT not only for pupils but for teachers as well, as ICT tools give more opportunities to communicate and collaborate with colleagues, with specialists of various fields and to systematically develop competences of the use of ICT. Development in this field depends greatly on the teacher's competence and motivation. The ability to use a variety of ICT tools depends on the teacher's competence, though on the other hand, the more often the teacher uses ICT, the more advantages of ICT tools he sees. That is why, the teacher is the most important factor that determines the usefulness of ICT and the level of the use of ICT during the lessons (Dagiene \& Kurilovas, 2008; Budreckaite \& Janiuniene, 2010, et al.) $27 \%$ of Lithuanian primary school teachers rely on their technical skills and do not see any barriers to the use of ICT measures in class. However, they rely on their social media skills less than EU average. (Survey of Schools: ICT in Education, 2013). The survey results confirm these trends. Discussing other SMART interactive technology advantages, teachers emphasized the possibility of primary school pupils to perform the tasks by touching, that is by writing, rubbing or drawing.

The analysis of the research participants' opinions about the advantages of ICT tools in primary education helped to select and to group the statements where all or most of the teachers cited undeniable advantages of ICT (table 1). This category is divided into sub-categories: The use of ICT in lessons of several subjects (no less than 3 subjects); promoting pupils' learning (tasks independently performed by pupils); education of pupils with special needs (individualization of teaching and learning); integration of educational content (internal and external integration of educational content).

Table 1 Advantages of ICT tools in primary education

\begin{tabular}{|l|l|}
\hline \multicolumn{1}{|c|}{ Sub-categories } & \multicolumn{1}{c|}{ Examples of statements } \\
\hline $\begin{array}{l}\text { The use of ICT in } \\
\text { lessons of several } \\
\text { subjects }\end{array}$ & $\begin{array}{l}\text { "the best I can use during all subjects", "what is most important it is } \\
\text { good for mathematics, the knowledge of the world, Lithuanian", "it } \\
\text { is for mathematics and English", "art and technology", "it is an } \\
\text { advantage because I can use it in lessons of all subjects". }\end{array}$ \\
\hline $\begin{array}{l}\text { Promoting } \\
\text { pupils' learning }\end{array}$ & $\begin{array}{l}\text { "it is important, they are so interested and repeat willingly", when } \\
\text { the text is on the screen, they enthusiastically read", "when they get } \\
\text { tired, they willingly work at the computer", "very well follow the } \\
\text { information on the screen", "to correct mistakes on the screen is }\end{array}$ \\
\hline
\end{tabular}




\begin{tabular}{|c|c|}
\hline & $\begin{array}{l}\text { much more interesting for them than on a sheet of paper", } \\
\text { "homework is done } 100 \% \text { ", even group learning is more } \\
\text { successful". }\end{array}$ \\
\hline $\begin{array}{l}\text { Education of } \\
\text { pupils with } \\
\text { special needs }\end{array}$ & $\begin{array}{l}\text { "perfect for gifted children occupation", "if they work more slowly", } \\
\text { "suitable for children with articulation problems", "good for those } \\
\text { who learn mathematics and know it well", "good opportunity to } \\
\text { repeat the exercises according to one's own pace". }\end{array}$ \\
\hline $\begin{array}{l}\text { Integration } \\
\text { educational } \\
\text { content }\end{array}$ & $\begin{array}{l}\text { "a good opportunity to link multiple lesson topics", "I associate } \\
\text { knowledge of the world lesson with a trip experience and } \\
\text { impressions", "in the website all the themes are integrated", "I use } \\
\text { the same task both in mathematics and in the knowledge of the } \\
\text { world", "the same story is also good at the Lithuanian language } \\
\text { lesson", "they get interested In the topic and then go on reading } \\
\text { themselves", "the text read in the textbook comes to life on the } \\
\text { screen". }\end{array}$ \\
\hline
\end{tabular}

In the sub-category 'The use of ICT in lessons of several subjects' teachers emphasized that existing ICT tool advantage lies in versatility, i.e. in the opportunity to use them in all or in almost all lessons. The teachers noted that they use not only the same existing ICT tools, but the same websites, media portals. So, teachers usually choose 3-5 tools and use them for a long time: "I have used this website for about 3 years already", "during a year maybe once I try to look for something new", "I am quite satisfied with the websites I use", I have learnt to create such type of tasks", etc. Compared with traditional (non-electronic) tools, ICT have obvious advantages of visualizing teaching material (e.g. spatial structures or moving images), researching and interpreting the interaction of various items, experimenting, consolidating knowledge, developing skills, giving the pupils instantaneous evaluation, searching for information, creatively expressing ideas and the viewpoint, communicating despite the distance, cooperating, etc.(Labutè \& Žemaitaitytè, 2015)

In the sub-category 'Promoting pupils' learning' teachers pointed out several meaningful advantages of the use of ICT: pupils willingly do repetition tasks, consolidate the material, performing tasks they retain their focus longer, pupil's curiosity is supported getting deeper into the theme, pupils are motivated to perform teaching tasks after classes. According to primary school teachers: "pupils repeat the tasks willingly", "if they have to do their homework using website, the homework is usually done by all the pupils", "they will do all the tasks", they always rejoice when they succeed in doing the tasks", "they can spend a lot of time at long tasks however, they do not ask for help", "they all work self-dependently", etc. These advantages of the use of ICT reflect in the national Conception of good school (2015). The conception emphasizes that the most important mission of successful school is good results of pupils' education achieved in pleasant, memorable and meaningful life and learning moments at 
school. Information and communication technology based education technology the most important feature of which is realization of educational activities mediated by technical means is also formed in modern society (Gudynas, et al., 2010). The use of ICT in class gives pupils autonomy. The teacher here is only a mediator but not the leader. The role of primary school teacher changes essentially as well. The teacher, disseminator of knowledge, becomes the teacher, indicating the direction showing where to go to achieve good results. Therefore, appropriately applying ICT in education process pupils are given more opportunities of independent learning (Dagiene \& Kurilovas, 2008; Gudoniene et al., 2013). Gudynas et al. (2010) state that working on the computer individually pupils themselves choose ways of work with information corresponding their learning style. Demonstrating their knowledge they can use various ICT tools by means of their creativity.

In the sub-category 'educations of pupils with special needs' primary school teachers emphasized versatility of ICT programs to individualize the content of primary education, according to pupils' needs (gifted pupils, pupils with special needs). Emphasizing advantages of ICT tools in this context the teachers mentioned: "I can choose separate tasks for one group of pupils and others for another group", "I can always choose different number of tasks", "when I got a pupil with special needs it took me long to seek for tasks suitable for him, and then I saw that it is easier to create tasks for interactive whiteboard myself", "when I start thinking about interactive tasks, I at once select the ones which can be done by the pupils working fastest and the ones which can be done by the pupils working more slowly", etc. One of the essential purposes of the Conception of a good school (2015) is pupils' personal growth, educational outcomes corresponding to the individual possibilities and constant educational progress reached by maximum individualizing educational process. The teachers, who participated in the study, point out advantages of ICT working in heterogeneous classes taking into account different pupils' learning needs and opportunities. However, teachers did not mention the internet and its potential in helping pupils to learn at home, to learn in an informal environment.

In the sub-category 'Integration of education content' the informants emphasized integrated features of ICT tools. Teachers of primary school named various internet websites, internet appliqués, games, which they chose because of the close links of given topics with the content of primary education, integration of different subjects in common themes, wider cognitive opportunities of pupils' social and natural environment. Primary school teachers pointed out internal and external integration opportunities of educational content: "in the program the same topic overviews historical facts, provides texts for reading comprehension", while doing various tasks pupils not only count, but also get acquainted with nature", "information is presented in such a way that while doing the tasks they 
learn even several subjects", "I find there well integrated topics of the knowledge of the world", etc. Namely integrity the informants emphasized as the essential criterion according to which they select ICT tools appropriate and inappropriate for use, eg. in mathematics (the object combination formation, labyrinths, roads, logic games), in the Lithuanian language (grammar rules, reading and writing), in music (recognition of recurring melodies and composition).

Targamadze et al. (2015) describing $\mathrm{Z}$ generation, i.e. school-age children, emphasized their close link with virtual (digital) environment, virtual environment created culture, conceptions of both new and computer literacy.

In the changed cultural situation, the teacher together with the pupils has actively participate in various activities of virtual (digital) culture, to become the leader and partner in the new educational contexts.

\section{Conclusions}

Summarizing the data of the research it can be said that the informants revealing various advantages of ICT use in lessons expressed their positive views to their application in education. Enumerating advantages of the use of ICT in primary education teachers pointed out advantages of the use of ICT in lessons of several subjects (in the lessons of no less than 3 subjects); promoting pupils' learning (pupils self-dependently do tasks during the lessons and at home); individualizing education of pupils with special needs; integration of education content (external and internal integration of education content). Primary school teachers - research participants - emphasized the meaning of ICT use to their own personal and professional development. They indicated that more and more often ICT tools become also the development tool of other professional competences. The research allows to foresee the possible trends of more effective use of ICT tools in schools of the country: the development of special professional competence of teachers (knowledge and ability to use a variety of ICT tools at the lesson, to identify special needs of primary school pupils, integrated education, etc.), a better primary schools supply with ICT tools and interactive presentations scenarios, accessibility of interactive teaching tools in the state language.

\section{References}

Brazdeikis, V. (2009). Informacinėmis ir komunikacinėmis technologijomis papildytų edukacinių aplinkų kaita. Informacijos mokslai, 50, 57-63.

Brazdeikis, V., \& Masaitis, M. (2012). Teaching Aids in Teaching and Learning Environments of Lithuanian Schools. Socialiniai mokslai, 76, 74-83. Downloaded from http://www.socsc.ktu.lt/index.php/Social/article/view/1964

Budreckienè, V., \& Janiūnaitè, B. (2010). Mokyklos vadovo inovacinès veiklos prielaidos: Lietuvos atvejis. Socialiniai mokslai,2 (68), 26-36. Downloaded from 
Rasa Braslauskiene, Gražina Šmitienè, Reda Vismantienè. Primary School Teachers' Approach to Advantages of ICT Use in Education

http://etalpykla.lituanistikadb.lt/fedora/objects/LT-LDB0001:J.04 2010 136717

3243244/datastreams/DS.002.0.01.ARTIC/content.

Creswell, J. W. (2009). Research Design: Qualitative, Quantitative and Mixed Methods Approaches. 3rd edition. Los Angeles: Sage Publications.

Dagienè, V., \& Kirilovas, E. (2008). Informacinès technologijos švietime: patirtis ir analizé. Monografija. Vilnius: Mokslo aidai.

Duoblienè, L. (2010). Medijų raštingumo ugdymas: globaliosios tendencijos ir lietuviškojo kelio paieškos. Santalka. Filologija. Edukologija, 18, 16-27.

Gudonienè, D., Rutkauskienè, D., \& Lauraitis, D. (2013). Pažangių mokymosi technologijų naudojimas ugdymo procese. Informacijos mokslai. 163, 96-107. Downloaded from: http://www.zurnalai.vu.lt/files/journals/163/articles/2064/public/96-107.pdf

Gudynas, P, Girdzijauskienè, R., Jakavonytè, D., \& Jevsikova, T. (2010). Inovatyviu mokymo (si) metodu ir IKT taikymas. Vilnius: Ugdymo plètotès centras.

Jucevičienè, P., \& Brazdeikis, V. (2012). The effectiveness of ICT competency evaluation strategies. Societal Innovations for Global Growth, 1, 367-375. Downloaded from http://socin.mruni.eu/wp-content/uploads/2012/12/B_2012-12-26.pdf

Kampylis, P., Punie, Y., \& Devine, J. (2015). Promoting Effective Digital - Age Learning - A European Framework for Digitally-Competent Educational Organizations. Downloaded from http://publications.jrc.ec.europa.eu/repository/bitstream/JRC98209/ jrc98209_r_ digcomporg_final.pdf

Prensky, M. (2001). Digital Native, Digital Immigrants. On the Horizon. MCB University Press, 9 (5). Downloaded from http://www.marcprensky.com/ writing/Prensky\%20\%20Digital\%20Natives\%20Digital\%20Immigrants\%20-\%20Part1.pdf

Ranguelov, S., Horvath, A., Dalferth, S., \& Noorani, S. (2011). Key Data on Learning and Innovation through ICT at school in Europe. Downloaded from https://ec.europa.eu/digital-single-market/sites/digitalagenda/files/Lithuania\%20country\%20profile.pdf

Saylik, A., \& Kalesnikienè, D. (2013). Mokytojo vaidmens kaita taikant informacines ir komunikacines technologijas pradinèse klasèse. Downloaded from http://www.upc.smm.lt/ugdymas/pradinis/rekomendacijos/failai/Mokytojo_vaidmens_k aita_taikant_IKT_pradinese_klasese_Zvirbliu_takas_2013_Nr_1_32-42.pdf

Survey of Schools: ICT in Education. Final Study Report (2013). European Commission, Luxembourg: Publications Office of European Union. Downloaded from: https://ec.europa.eu/digital-single-market/sites/digital-agenda/files/KK-31-13-401-ENN.pdf

Targamadzè, V., Girdzijauskienè, S., \& Šimelionienė, A. (2015). Naujoji (Z) karta - prarastoji ar dar neatrastoji? Specialiosios pedagogikos ir psichologijos centras. Downloaded from http://www.esparama.lt/documents/10157/490675/2015+Naujoji+Z+karta.pdf 134dab319-bb9b-4041-8365-5f88e2b8db52

Targamadzè, V. (2014). Z karta: charakteristika ir ugdymo metodologinès linkmès įžvalga. Tiltai, 4, 95-104. Klaipedos universiteto leidykla.

Wastiau, P., Blamire, R., Kearney, C., Quittre, V., Van de Gaer, E., \& Monseur, C. (2013). The Use of ICT in Education: a survey of schools in Europe. European Journal of Education, (I), 11-27. Blackwell Publishing Ltd., Oxford.

Labute, Ž., \& Žemaitaitytè, I. (2015). Informacinių komunikacinių technologijų pritaikymo galimybės socialinio ugdymo pamokose. Socialiniu mokslu studijos. 2015, 7 (2), 292304. Downloaded from: http://www.mruni.eu/en/mokslo_darbai/SMS/ 